\title{
Species diversity and distribution of ruderal flora on landfills in Maradi city, Niger
}

\author{
Laminou M. Ousmane ${ }^{1}$, Abdourahamane I. Salamatou ${ }^{2}$, Dan Guimbo Iro ${ }^{3}$, Beido M. \\ Abdoul-Aziz ${ }^{4}$, Mahamane Ali², Ozer Pierre ${ }^{5}$ ${ }^{2}$ Department of Biology, University of Diffa, Diffa, Niger
${ }^{3}$ Department of Rural Engineering and Waters \& Forests, Abdou Moumouni University of Niamey, Niamey, Niger
${ }^{4}$ Department of Biology and Techniques, Dan Dicko Dankoulodo University of Maradi, Maradi, Niger
${ }^{5}$ Department of Sciences and Environmental Management, University of Liège, Liege, Belgium \\ ${ }^{1}$ Department of Rural Engineering and Waters \& Forests, Dan Dicko Dankoulodo University of Maradi, Maradi, Niger
}

\begin{abstract}
Waste management continues to be a critical environmental issue in cities. It impacts on the well being of the population, the environment and the biodiversity. In the city of Maradi, in Niger, more interest is given to the problem in order to understand the whole waste management system. It is in this context that this study is carried out to investigate on the role of ruderal flora on the municipal solid wastes dumpsites and landfill sites in Maradi city. The specific objectives are to determine the floristic diversity and distribution of ruderal flora on the municipal solid waste disposal sites, and to identify potential species that can play an important role in the phytoremediation of these sites. In total, 65 species belonging to 52 genera and 24 families were recorded. These species can be categorised into two groups containing anthropic and nitrophilic species according to the ascending Hierarchical Classification (AHC) at $25 \%$ similarity. Characteristic species of the first group G1 are Amaranthus viridis and Cucurbita pepo, and Datura innoxia and Cucumis melo for the second group G2. Other ruderal species, namely Amaranthus spinosus L., Amaranthus viridis L., Celosia trygina L., Datura innoxia Mill., and an introduced woody species, Cuphea hyssopifolia Kunth., found are not included in the Maradi city list of species. Datura innoxia, Amaranthus viridis and Amaranthus spinosus are species known to tolerate different degrees of pollution and their ecology should be further study to better understand how they can be used for phytoremediation on this kind of sites.
\end{abstract}

Keywords-Landfills, flora, species, diversity, distribution, Maradi.

\section{INTRODUCTION}

Cities in developing countries are subject, on one hand, to a high demographic expansion and on the other, to a massive and fast rural urban migration (Seidl and Mouchel, 2003). Effects of globalization have led population of several large West African cities to an increase in their consumption resulting to an exorbitant increase of household waste (Oxfam-Québec, 2007). Waste production, particularly the solid ones, in urban areas is growing at an unprecedented rate and takes large proportions in those developing countries where their disposal has become an issue of growing concern and paramount (Redjal, 2015).

However, the garbage accumulation and local population exposure create discomforts and affect the population health (Maiti et al., 2004; Ouedraogo, 2010).

Consequently, there is a proliferation of disease transmitters and deterioration of the urban environment quality (Tchaou, 2011). Furthermore, dumpsites are characterized by the daily presence of household waste.

The wastes, in many cases, contain matters from animal, vegetal (food rest, organic debris ...) and mineral sources. Thus, they contribute highly to the soil enrichment of these sites especially in organic matter and nutrients.

Also, these sites offer very specific ecological conditions on one hand by the accumulation of organic matter and, secondly, by the existence of a certain contamination by heavy metals. Indeed, several heavy metals buried during waste storage have been identified in urban landfills and dumps, namely, Aluminium ( $\mathrm{Al}$ ), Lead $(\mathrm{Pb})$, Cadmium $\mathrm{Cd})$, Zinc ( $\mathrm{Zn})$, Copper ( $\mathrm{Cu})$, Iron ( $\mathrm{Fe})$, Arsenic (As), etc. (Jourdan et al., 2005; Kimani, 2007; Beyene and Banerjee, 2011; Tankari et al., 2013; Abdourahamane et al., 2015).

The presence of these organic matters, inorganic and metal pollutants often alters biodiversity in the area. It leads to the modification of ecological factors that often results in dynamics of plant association and floristic composition of the environment (Falcon, 2012). Also, the transfer of metals, particularly lead, zinc and copper, to aquifers or to plants can lead to harmful effects on people through the food chain because of their toxicity (Fifi, 2009; Jourdan et al., 2005; Tankari, 2011). It is well known that hyper-accumulating and accumulating ruderal 
plants accumulate metals, whatever the concentration rate in soil (Leteinturier \& Malaisse, 1999). For example, according to Prasad (2001), Amaranthus spinosus and Amaranthus spinosus accumulate cadmium in their root, stem and leaves while Abou-Shanab et al. (2007) reported that Cynodon dactylon accumulate lead, cooper and zinc in their root and shoot. Hence, this recognized capacity of ruderal species to accumulate heavy metal can be used in contaminated sites phytoremediation which is one of the biological soil remediation technologies (Anoliefo et al., 2008).

In the city of Maradi in Niger, sanitation is one of the environmental priorities. Indeed, solid waste management, particularly that of household waste, is considered by the city officials as the main sanitation challenge in this city. Solid waste generation sources are mainly households, shops (markets) and industries. Waste disposal techniques and dumpsite management is insufficient in order to avoid contamination of soil, water, biodiversity and humans in this city. Abdourahamane et al (2015) even found that in the city of Maradi, the storage of solid waste on the different dumpsites and landfills types is not efficient against the heavy metal contamination such as zinc, cadmium and lead. The limited financial and technical resources also contribute to the mismanagement of the sites. It is in this context that the present study was carried out to investigate the role of ruderal flora on the municipal solid wastes dumpsites and landfill sites in Maradi city. The specific objectives of this work are to determine the floristic diversity and distribution of ruderal flora on the municipal solid waste disposal sites, and to identify potential species that can play an important role in the phytoremediation of these sites.

\section{MATERIALS AND METHODS}

\subsection{Study area}

The study was carried out in Maradi city which is the main economic centre of Niger. This city is located between latitudes $13^{\circ} 32^{\prime} \mathrm{N}$ to $13^{\circ} 26^{\prime} \mathrm{N}$ and longitudes $7^{\circ} 40^{\prime} \mathrm{E}$ to $7^{\circ} 13^{\prime} \mathrm{E}$, and covers 8269 hectares (Fig. 1). The climate is of sahelo-sudanian type with an average temperature varying from $23.21^{\circ} \mathrm{C}$ in cold period to $40^{\circ} \mathrm{C}$ in hot period, an average relative humidity of $40.10 \%$ (Direction Nationale de la Météorologie, 2013). The mean annual rainfall, calculated over the past thirty years is around $476.89 \mathrm{~mm}$. The hydrographical network is dominated the valley of Goulbi Maradi and some semipermanent water points. This city is located on a plateau with an average altitude of around $400 \mathrm{~m}$. The soils of Maradi region are tropical ferruginous, rich in silt in the Goulbi zone.

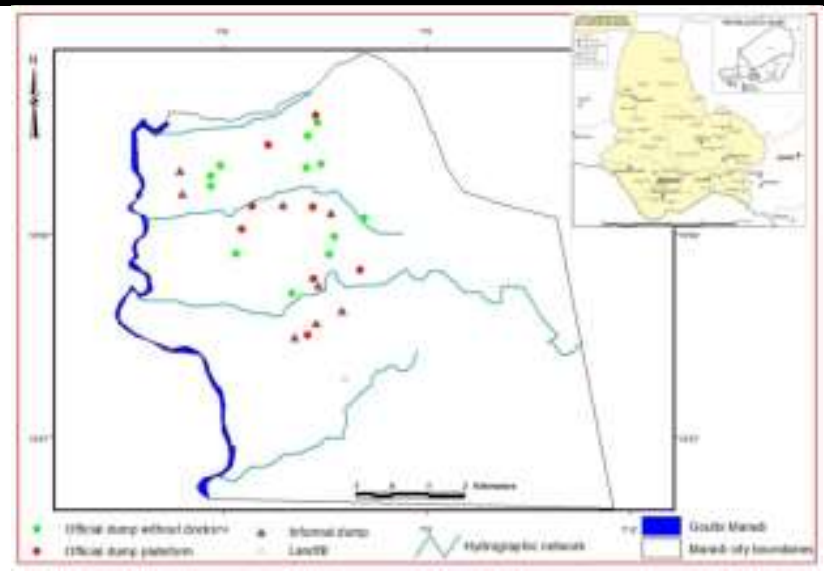

Fig.1: Study area and the sampling sites location

Maradi City has a population of 264,897 inhabitants with an annual growth rate of $4.3 \%$ in 2012 (INS, 2013). The availability of water, during a large part of the year allow the development of rainy and irrigated agriculture which is practiced by about $40 \%$ of the population of this city. Waste management in Maradi city is provided by municipal services. The waste disposal is done in three steps (Abdourahamane et al., 2015). Firstly, the waste is temporarily stored in containers on the production sites which include homes, markets, main streets, hospitals, etc. Secondly, they are transferred by local people to the dumpsites where they are finally collected by municipal services to be stored in the landfill sites and very rarely buried. Recycling is hardly practiced. However, there are a few collectors of objects from landfills and dumpsites in order to transform into useful domestic tools or sell them to other interested users

\subsection{Sites description}

The sampling sites are dumps and landfills (Fig. 2).

- Dumpsites: They are of two types: official and informal dumpsite or uncontrolled.

Official dumps are places equipped with dumpsters or garbage containers for waste collection (Concept, 2007). These dumpsters have a capacity of $5.5 \mathrm{~m}^{3}$ and more or less regularly removed and disposed of in landfills or other sites. There are two categories of official dumpsites in Maradi city: (i) the "dumps platforms" that are equipped with a three-compartment system with a dock for easy access to the dumpster, a terrace of about $5 \mathrm{~m}^{3}$ in the downstream portion in contact with two or three containers with a small hut for on-site caretaker, and (ii) the "official dumps without docks", the most abundant in the city, which are simply characterized by the presence of a dumpster or other container. They are officially recognized by the municipality. Informal or uncontrolled dumps, unlike officials, are waste consolidation sites without official municipality permission, created by neighbouring inhabitants because of the lack of formal 
dumpster or the relatively long distance to an official dumpsite, making it inaccessible (Concept, 2007). They are usually located in inappropriate places, in the streets, often alongside health or education infrastructure, etc.

- Landfills: Last link in the waste disposal chain, these are quarries or areas adjacent to the city where the collected waste from dumpsites are eliminated. They are often very large uncontrolled dumpsites.

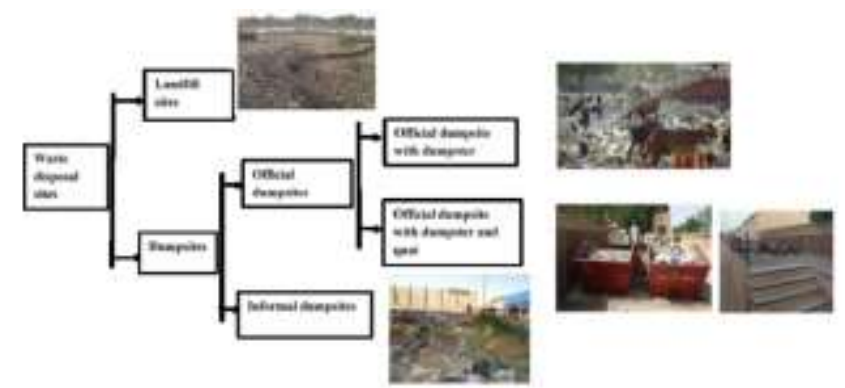

Fig.2: Different waste disposal sites (adopted from Abdourahamane et al., 2015)

\subsection{Sampling and Data collection on the herbaceous} flora

Herbaceous plants sampling was carried out on six official dumpsites, six informal dumpsites and four landfill sites. Data collection was done in a $100 \mathrm{~m} 2$ sampling plots $(10 \mathrm{~m} \times 10 \mathrm{~m})$ on every site. Surveys were conducted along transects considering the main roads that run alongside these sites as main line. Transects were established perpendicular to this line towards landfills. The equidistance between adjacent transects is $15 \mathrm{~m}$ and $10 \mathrm{~m}$ between neighbouring plots on the same transect. Given the area covered by vegetation on dumps and landfills sites, plots were established to cover areas with vegetation as representative of the study site, as well as possible. Thus, on each plot, 2 transect lines were used for data collection. A total of 30 records were made on dumpsites and landfill sites.

Phytosociological records were made using the BraunBlanquet sigmatiste method (1932). This method has the advantage to draw up an exhaustive list of all the plant species present in the plot. These records were completed by the Daget and Poissonet linear method (1971). Two lines of quadrats points were performed in each plot. Each line has $20 \mathrm{~m}$ of length and includes 100 points of contact.

\subsection{Data analysis}

Phytosociological records of the herbaceous layer collected were formed into a matrix of plant species abundance-dominance. This expresses the number of individuals of the same species and their degree of recovery. This matrix has been subjected to an Ascending
Hierarchical Classification (AHC) using PC ORD software version 5. The resulted information table is summarized in a dendrogram. Analysis allows discriminating plant communities on the basis of similarity at the Sorensen index level (Legendre and Legendre 1998). Shannon and Weaver diversity (1949) and Pielou equitability (1966) indexes were calculated in order to analyze vegetation diversity of dumpsites and landfill sites.

\section{RESULTS AND DISCUSSION}

In this environmental context, floristic richness analysis of dumpsites and landfill sites of Maradi city revealed a relatively high floristic diversity despite the hash living conditions for many species. On the study area, 65 species belonging to 52 genera and 24 families were recorded (Table 1). Fabaceae and convolvulaceae were the most represented families with 6 species each, followed by Cucurbitaceae and Poaceae with 5 species each, the Malvaceae with 4 species. The families of Amaranthaceae, Acanthaceae, Cyperaceae, Solanaceae, Pedaliaceae and Rubiaceae are represented by 3 species each. Caesalpiniaceae, Aizoaceae, Commelinaceae, Euphorbiaceae and Tiliaceae families have 2 species each. Other families are Asclepiadaceae, Asteraceae, Capparidaceae, Lamiaceae, Molluginaceae, Nyctaginaceae and Zygophyllacea represented by one single species.

Table.1: Floristic list of dumpsites and landfill sites of

\begin{tabular}{|c|c|}
\hline \multicolumn{2}{|l|}{ Maradi city } \\
\hline Species & Families \\
\hline Acanthospermum hispidum DC. & Asteraceae \\
\hline $\begin{array}{l}\text { Alysicarpus ovalifolius (Schum. Et } \\
\text { Thonn.) J. Léonard. }\end{array}$ & Fabaceae \\
\hline Amaranthus spinosus L. & Amaranthaceae \\
\hline Amaranthus viridis $\mathrm{L}$. & Amaranthaceae \\
\hline Boerhavia erecta L. & Nyctaginaceae \\
\hline $\begin{array}{l}\text { Borreria scabra (schum.EtThonn.) } \\
\text { K.Schum }\end{array}$ & Rubiaceae \\
\hline Borreria stachydea (DC) hutch. Et Dalz & Rubiaceae \\
\hline Cassia mimosoides $\mathrm{L}$. & Caesalpiniaceae \\
\hline Cassia occidentalis $\mathrm{L}$. & Caesalpiniaceae \\
\hline Celosia trygina $\mathrm{L}$. & Amaranthaceae \\
\hline Cenchrus biflorus Roxb. & Poaceae \\
\hline Ceratotheca sesamoides Endl. & Pedaliaceae \\
\hline Citrullus colocynthis (L.) Schard. & Cucurbitaceae \\
\hline $\begin{array}{l}\text { Citrullus lanatus (thunb.)Matsumara et } \\
\text { makai }\end{array}$ & Cucurbitaceae \\
\hline Cleome viscosa $\mathrm{L}$ & Capparidaceae \\
\hline Commelina benghalensis L. & Commelinaceae \\
\hline
\end{tabular}


Commelina forskalaei Vahl.

Corchorus tridens L.

Cucurbita pepo L.

Cyperus esculentus L.

Cyperus rotundus $\mathrm{L}$.

Dactyloctenium aegyptium (L.) Willd.

Datura innoxia Mill.

Digitaria horizontalis Wild.

Echinochloa colona (L.) Link

Eleusine indica (L.) Gaertn

Eragrostis tremula Steud.

Euphorbia hirta L.

Evolvulus alsinoides (L.) L.

Gisekia pharnacioides L.

Hibiscus asper Hook. f.

Hibiscus sabdariffa L.

Indigofera astragalina DC.

Indigofera pulchera Willd.

Ipomoea coptica (L.) Roth. ex. Roem. et

Schult.

Ipomoea dichroa Hachst.Ex Choisy

Ipomoea vagans Bak.

Jacquemontia tamnifolia (L.) Griseb.

Kyllinga squamulata Thonn.Exvahl.

Leucas martinicensis (Jacq.) R. Br.

Merremia tridentata (L.) Hallier. f.

Mitracarpus scaber (Sw.) DC.

Mollugo nudicaulis Lam.

Momordica balsamina L.

Monechma ciliatum (Jacq.) Milne. Red.

Mukia maderaspatana (L.) Roem.

Pennisetum pedicellatum Trin.

Pergularia tomentosa $\mathrm{L}$.

Peristrophe bicalyculata (Retz)Nees .

Peristrophe paniculata (Forssk.) Brum mitt

Phyllanthus pentandrus Schum. et

Thonn.

Physalis angulata L.

Physalis lagascae Roem. Et Schult.

Ricinus communis L.

Rogeria adenophylla J. Gay.

Sesamum alatum Thon.

Sesbania pachycarpa DC.

Sida alba L.

Sida cordifolia L.

Solanum lycopersicum L.
Commelinaceae

Tiliaceae

Cucurbitaceae

Cyperaceae

Cyperaceae

Poaceae

Solanaceae

Poaceae

Poaceae

Gramineae

Poaceae

Euphorbiaceae

Convovulaceae

Aizoaceae

Malvaceae

Malvaceae

Fabaceae

Papilonaceae

Convolvulaceae

Convolvulaceae

Convolvulaceae

Convolvulaceae

Cyperaceae

Lamiaceae

Convolvulaceae

Rubiaceae

Molluginaceae

Cucurbitaceae

Acanthaceae

Cucurbitaceae

Graminea

Asclepiadaceae

Acanthaceae

Acanthaceae

Euphorbiaceae

Solanaceae

Solanaceae

Euporbiacea

Pedaliaceae

Pedaliaceae

Fabaceae

Malvaceae

Malvaceae

solanaceae
Tribulus terrestris Viv.

Trienthema portulacastrum (L.) L.

Triumfetta pentandra A. Rich.

Vigna unguiculata (L.) Walp. Subsp.

Unguiculata

Zornia glochidiata Reichb. Ex DC.

Zygophyllaceae

Aizoaceae

Tiliaceae

Fabaceae

Fabaceae

The dendrogram derived from Ascending Hierarchical Classification (AHC) has allowed individualizing the different plant groups. Analysis divided the records into two groups (Fig. 3) at the level of 25\%: Amaranthus viridis and Cucurbita pepo group (G1) and Datura innoxia and Cucumis melo group (G2).

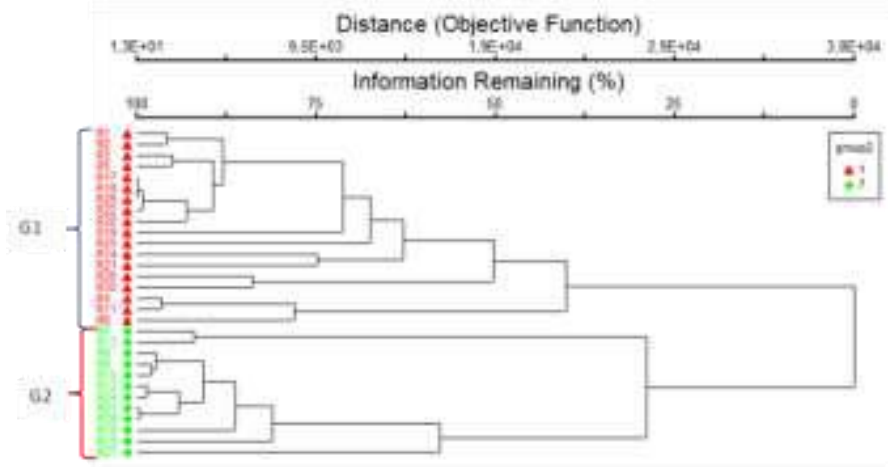

Fig.3: Dendrogram of plant group of species found on the different dumpsites and landfills in Maradi city

The group 1 of Amaranthus viridis and Cucurbita pepo is composed of 44 species (18 records) (Table 2). Amaranthus viridis, Cucurbita pepo, Amaranthus spinosus, Corchorus tridens are the characteristic species of this group. The companion species are Sida cordifolia, Trianthema portulacastrum and Cleome gynandra. This group belongs to the class of Ruderali mahihotetea Taton 1949, class containing anthropic and nitrophilic groups, trampled, from rubble and roadsides. The ShannonWeaver index, of 4.46 bits, reveals a high diversity within this group. The equitability index, of 0.94 bits, indicates that several species participate in the recovery.

Table 2: Floristic list of the Group 1

\begin{tabular}{ll}
\hline Species & Families \\
\hline Acanthospermum hispidum DC. & Asteraceae \\
Alysicarpus ovalifolius (Schum. Et & Fabaceae \\
Thonn.) J. Léonard. & Amaranthaceae \\
Amaranthus spinosus L. & Amaranthaceae \\
Amaranthus viridis L. & Nyctaginaceae \\
Boerhavia erecta L. & Rubiaceae \\
Borreria & \\
scabra $($ schum.EtThonn.)K.Schum & Rubiaceae \\
\hline
\end{tabular}


Cassia mimosoides $\mathrm{L}$.

Caesalpiniaceae

Cassia occidentalis L.

Celosia trygina $\mathrm{L}$.

Cenchrus biflorus Roxb.

Citrullus lanatus (thunb.)Matsumara et makai

Cleome viscosa L.

Commelina benghalensis L.

Commelina forskalaei Vahl.

Corchorus tridens L.

Cucurbita pepo L.

Cyperus esculentus L.

Dactyloctenium aegyptium (L.) Willd.

Datura innoxia Mill.

Digitaria horizontalis Wild.

Eragrostis tremula Steud.

Euphorbia hirta L.

Hibiscus sabdariffa L.

Indigofera pulchra Willd.

Ipomoea coptica (L.) Roth. ex. Roem. et Schult.

Ipomoea dichroa Hachst.Ex Choisy

Ipomoea vagans Bak.

Kyllinga squamulata Thonn.Exvahl.

Leucas martinicensis (Jacq.) R. Br.

Mitracarpus scaber (Sw.) DC.

Monechma ciliatum (Jacq.) Milne. Red.

Pennisetum pedicellatum Trin.

Pergularia tomentosa L.

Peristrophe bicalyculata (Retz)Nees .

Ricinus communis L.

Rogeria adenophylla J. Gay.

Sesamum alatum Thon.

Sesbania pachycarpa DC.

Sida cordifolia L.

Solanum lycopersicum L.

Tribulus terrestris Viv.

Trienthema portulacastrum (L.) L.

Zornia glochidiata Reichb. Ex DC.

The group 2 of Datura innoxia and Cucumis melo is composed of 40 species (12 records) (Table 3$)$. The characteristic species of this group are Datura innoxia, Cucumis melo, Physalis lagascae, Sida cordifolia, Ricinus communis. The companion species are Amaranthus viridis, Corchorus tridens, Cyperus rotondus, Cleome gynandra. Like the previous one, this group belongs to the syntaxon of the Ruderali

Malvaceae

Convolvulaceae

Convolvulaceae

Convolvulaceae

Cyperaceae

Lamiaceae

Rubiaceae

Acanthaceae

Poaceae

Asclepiadaceae

Acanthaceae

Euphorbiaceae

Asclepiadaceae

Fabaceae

Malvaceae

Solanaceae

Zygophyllaceae

Molluginaceae

Fabaceae manihotetea Taton 1949. The value of the ShannonWeaver index, of 3.39 bits, shows that the diversity within this group is moderate. The equitability index, of 0.96 bits, shows that a several species participate in the recovery.

Table 3: Floristic list of the Group 2

\begin{tabular}{ll}
\hline Species & Families \\
\hline Acanthospermum hispidum DC. & Asteraceae \\
Alysicarpus ovalifolius (Schum. Et & Fabaceae \\
Thonn.) J. Léonard. &
\end{tabular}

Amaranthus spinosus L.

Amaranthaceae

Amaranthus viridis L.

Amaranthaceae

Boerhavia erecta L.

Nyctaginaceae

Borreria stachydea (DC) hutch. Et Dalz Rubiaceae

Cassia occidentalis L.

Caesalpiniaceae

Celosia trygina $\mathrm{L}$.

Amaranthaceae

Cenchrus biflorus Roxb.

Citrullus lanatus (thunb.)Matsumara et

makai

Cleome viscosa $\mathrm{L}$.

Poaceae

Pedaliaceae

Cleome gynandra $L$.

Commelina benghalensis L.

Cucurbitaceae

Commelina forskalaei Vahl.

Cappparaceae

Capparaceae

Commelinaceae

Corchorus tridens L.

Commelinaceae

Tiliaceae

Cucumis melo L.

Cucurbita pepo $\mathrm{L}$.

Cucurbitaceae

Cyperus esculentus L.

Cucurbitaceae

Cyperaceae

Dactyloctenium aegyptium (L.) Willd.

Poaceae

Datura innoxia Mill.

Solanaceae

Digitaria horizontalis Wild.

Poaceae

Eragrostis tremula Steud.

Euphorbiaceae

Euphorbia hirta L.

Indigofera pulchra Willd.

Ipomoea vagans Bak.

Euphorbiaceae

Fabaceae

Convolvulaceae

Ocimum gratissimum $L$.

Lamiaceae

Mariscus squarrosus (L.) C.B. Cl.

Cyperaceae

Pennisetum typhoides Stapf.

Poaceae

Pennisetum pedicellatum Trin.

Poaceae

Peristrophe bicalyculata (Retz)Nees .

Acanthaceae

Physalis lagascae Roem. Et Schult.

Solanaceae

Ricinus communis L.

Euphorbiaceae

Rogeria adenophylla J. Gay.

Pedaliaceae

Sesamum alatum Thon.

Pedaliaceae

Sesbania pachycarpa DC.

Fabaceae

Sida cordifolia L.

Malvaceae

Solanum lycopersicum L.

Solanaceae

Tribulus terrestris Viv. 
Trienthema portulacastrum (L.) L.

Aizoaceae

Triumfetta pentandra A. Rich.

Tiliaceae

The Sorensen index of similarity between the two groups is of $42.98 \%$, thus showing that they are each other independents. The analysis shows a relatively high floristic richness depending on the considered group. Thus, comparison between groups showed a high diversity within G1 than in G2. Comparison between the floristic lists of dumps and landfills sites with those of Maradi Tannery (Mahamane, 2012) and Maradi (Saadou, 1990) was done using the similarity Sorensen index (Table 4). Analysis of the results shows very low similarities between the three floristic lists. The highest rate is obtained between the floristic lists of dumps and landfills sites and Maradi Tannery.

Table 4: Similarity matrix between the floristic lists(in \%)

\begin{tabular}{lccc}
\hline Floristic lists & $\begin{array}{c}\text { Dumps and } \\
\text { landfills sites }\end{array}$ & $\begin{array}{c}\text { Maradi } \\
\text { Tannery }\end{array}$ & $\begin{array}{c}\text { Maradi } \\
\text { list }\end{array}$ \\
\hline $\begin{array}{l}\text { Dumps and } \\
\text { landfills sites }\end{array}$ & - & & \\
$\begin{array}{l}\text { Maradi } \\
\text { Tannery }\end{array}$ & 31,25 & - & \\
Maradi list & 20,74 & 17 & - \\
\hline
\end{tabular}

Some of herbaceous species found on the dumps and landfills sites are not included in the Maradi floristic list. These are ruderal species, namely Amaranthus spinosus L., Amaranthus viridis L., Celosia trygina L. and Datura innoxia Mill., and an introduced woody species, Cuphea hyssopifolia Kunth..

The very low similarities found between the floristic list of dumps and landfills sites with those of Maradi Tannery (from 2012) and Maradi (from 1990) is due to the urbanization effect. Therefore to ecological conditions change that occurs in the city over the years and the existence of particular conditions at dumps and landfills sites. The specific ecological conditions of these sites are characterized, firstly, by an overabundance of organic matter and a sun exposure throughout the year and, secondly, by the existence of some heavy metals contamination (Abdourahamane et al., 2015). In fact, ruderal species are the best represented in the two groups. Also, the toxicity of heavy metals operates a very thorough selection, eliminating many species that are found in these places. Indeed, the very severe selective screening imposed by metal toxicity can cause rapid evolution towards high tolerance levels. Although the flora of dumps and landfills habitats comes from ordinary habitats, species that compose it gather in particular vegetation compared to local ordinary habitats (Ernst, 1974 in Falcon (2012)). Plant colonization of these habitats is partly driven by the populations of existing non-tolerant plants nearby. The $\mathrm{pH}$ of these sites plays an important role in this selection. It act, on one hand, directly on the level of nutrients availability in the substrate, but also, one the other hand, on soil microbial activity causing organic matter decomposition and its mineralization. A pH between 6.5 and 8 is favorable for the installation of ground vegetation cover of herbaceous types (Henry et al., 2011). Characteristically, the growth of woody species (trees and shrubs) is inhibited, leading to the development of plant groups purely herbaceous or slightly shrub (Falcon, 2012). This would explain the predominance of ruderal species in the floristic composition of the dumps and landfills sites vegetation. In addition, some species, like Datura innoxia, Amaranthus viridis and Amaranthus spinosus of the ruderal flora, found exclusively in these sites, have the ability to tolerate heavy metals presence and accumulation at variable rates including those found by Abdourahamane et al. (2015) in the study area (Kouamé et al., 2006; Jean, 2007; Dazy, 2008; Atayese, 2009; Messou et al., 2013; Messou et al., 2015). In fact, several studies have showed that $D$. innoxia tolerates many heavy metals accumulation: Jean (2007) for zinc, nickel and chrome; Salt et al. (1995) for cadmium and Vaillant et al. (2005) for zinc. While many others have shown that the heavy metals tolerance and phytoaccumulation capacity of A. viridis and A. spinosus: Messou et al. (2013) for cadmium, lead, zinc, iron etc.; Prassad (2001) for cadmium, zinc, lead, cooper and iron; Abe et al. (2001) for cadmium, etc. These are metallicolous or metallophytes species. They develop special strategies to survive and colonize these environments with contrasting ecological conditions. Indeed, metallicolous species, tolerant to metals, have the ability to survive and reproduce on toxic or adverse soil to most of others organisms because of metal contamination, and metallophytes would be endermic, species associated with soil contrasting chemical conditions.

Finally, the study of the ecology of species counted on landfills and dumps sites in Maradi city reveals the preponderance of ruderal species. That illustrates the impact of landfills and dumpsites on the herbaceous vegetation which tends towards a homogenization in ruderal flora.

\section{CONCLUSION}

The preponderance of those exclusive ruderal species in the floristic composition of the majority of sites illustrates the natural capacity of pollutant removal. Waste management through phyto-remedation is an alternative 
that should be further investigated by the municipal sanitation services. Datura innoxia, Amaranthus viridis and Amaranthus spinosus. species are suitable candidates in phytoremediation project and an ecological waste management system in this city of Maradi.

\section{ACKNOWLEDGEMENTS}

Our thanks go to the SOMAIR Company for their financial support throughout our research activities. We also wish to acknowledge the contribution of the Municipality of Maradi that facilitated our field work and all other people who contributed to this research activity.

\section{REFERENCES}

[1] Abdourahamane, I.S., Laminou, M.O., Tahirou, I.D., Abdoul-Aziz, M.B., Sani, I.S., Boubacar, M.M., Mahamane, A., Saadou, M. (2015). Impact of Solid Waste Disposal System on Soil in Maradi City (Niger Republic): A Preliminary Study of Heavy Metal Contamination. International Journal of Current Microbiology and Applied Sciences. 4 (5):650-659.

[2] Abe T, Fukami, M. Ogasawara, M. (2008). Cadmium accumulation in the shoots and roots of 93 weed species. Soil Sci Plant Nutr. 54:566-573.

[3] Abou-Shanab, R., Ghanem, N., Ghanem, K., AlKolaibe, A. (2007). Phytoremediation potential of crop and wild plants for multi-metals contaminated soils. Res J Agric Biol Sci. 3(5):370-376.

[4] Anoliefo, G.O., Ikhajiagbe, B., Okonokhua, B.O., Edegbai, B.O., Obasuji, D.C. (2008). Metal tolerant species distribution and richness in and around the metal based industries: possible candidates for phytoremediation. Afr J Environ Sci Technol. 2(11):360-370.

[5] Beyene, H.B., Banerjee, S. (2011). Assessment of the Pollution Status of the Solid Waste Disposal Site of Addis Ababa City with Some Selected Trace Elements, Ethiopia. World Applied Sciences Journal. 14(7):1048-1057.

[6] Braun-Blanquet, J. (1932). Plant sociology. (Transl. G. D. Fuller and H. S. Conrad). McGraw-Hill, New York. 539 pp

[7] Concept, (2007). Etude de faisabilité de la gestion des déchets ménagers dans les villes de Niamey et Maradi. Final report, 119 p.

[8] Daget, P., Poissonet, J. (1971). Une méthode d'analyse phytosociologique des prairies. Critères d'applications. Ann. Agron. 22(1):5-41.

[9] Direction Nationale de la Météorologie (2013). Prévisions climatiques saisonnières. Ministry of Transport, Niger Republic. http://www.meteoniger.org/
[10]Falcon, M.P. (2012). Trésor minéral et diversité végétale, Ecologie et biodiversité des sites métallifères. Société Française d'Ecologie. https://www.sfecologie.org/regard/r32-m-p-faucon/

[11]Fifi, U. (2009). Contamination des eaux souterraines : une situation particulière dans les villes des pays en développement. Master dissertation, Faculty of Environmental Sciences, Quisqueya University.

[12]Henry, E., Cornier, T., Toussaint, B., Duhamel, F., Blondel, C. (2011). Guide pour 1 utilisation de plantes herbacées pour la végétalisation à vocation écologique et paysagère en Région Nord-Pas de Calais - Centre régional de phytosociologie / Conservatoire botanique national de Bailleul, $56 \mathrm{p}$.

[13] Institut National de la Statistique (2012). Recensement Général de la Population et de l'Habitat. Niger Republic, Niamey, INS-Niger. 10 p.

[14] Jean, L. (2007). Mobilisation du chrome et du nickel à partir de sols contaminés, en présence de complexants : Transfert et accumulation de ces métaux chez Datura innoxia. PhD dissertation, Faculty of Sciences and Techniques, University of Limoges.

[15] Jourdan, B., Piantone, P., Lerouge, C., Guyonnet, D. (2005). Atténuation des métaux à l'aval des sites de stockage des déchets-synthèse bibliographique. Report BRGM/RP-54417-FR, 109p.

[16] Kimani, N. G. (2007). Environmental Pollution and Impacts on Public Health: Implications of the Dandora Municipal Dumping Site in Nairobi, Kenya. Report Summary by Njoroge G. Kimani, in cooperation with United Nations Environment Programme and the St. John Catholic Church, Korogocho.

http://www.unep.org/urban_environment

[17]Legendre, P., Legendre, L. (1998). Numerical ecology. Developments in Environmental Modelling, 20:235-245.

[18]Leteinturier, B., Malaisse, F. (1999). De la réhabilitation des sols pollués par l'activité minière au cuivre en Afrique Centro-australe. Bull Séance Acad R Sci Outre-mer. 45(4) :535-554.

[19] Mahamane, A. M. (2013). Effets de la modernisation de la tannerie de Maradi sur l'impact de ses activités sur la qualité des eaux, du sol et de la végétation. Master dissertation, Faculty of Sciences and Techniques, University of Maradi.

[20] Maiti, R. K., Pinero, J. L. H., Oreja, J. A. G., Santiago, D. L. (2004). Plant based bioremediation and mechanisms of heavy metals tolerance of plants: a review. Proc Indian Natl Sci B. 70(1):1-12. 
[21] Messou, A., Coulibaly, L., Doumbia, L., Gourene, G. (2013). Plants diversity and phytoaccumulators identification on the Akouedo landfill (Abidjan, Côte d'Ivoire). African Journal of Biotechnology. 12(3):253-264.

[22] Messou, A., Ouattara, P. J. M., Kone, T., Alangba, S. C., Coulibaly, L. (2015). Phytoextraction potential of three endogenous Amaranthaceae species grown on the Akouédo landfill (Abidjan, Côte d'Ivoire). Journal of Biodiversity and Environmental Sciences. 7(5):83-95.

[23] Ouedraogo, E. U. R. (2010). La gestion urbaine dans les pays du Sud. Master dissertation, Department of Geography, University of Ouagadougou.

[24] Oxfam-Québec, (2007). Un modèle de gestion communautaire des déchets solides ménagers en Afrique de l'Ouest. ISBN 978-2-923130-08-8.

[25] Pielou, E. C. (1966). The measurement of diversity in different types of biological collections. J Theor Biol. 13:131-144

[26] Prasad, M. N. V. (2001). Bioremediation potential of Amaranthaceae. In: Proceeding of the 6th International in situ and on site bioremediation symposium, 4-7 june, 2001, San Diego, California, USA.

[27] Redjal, O. (2015). Vers un développement urbain durable: Phénomène de prolifération des déchets urbains et stratégie de préservation de l'écosystème Exemple de Constantine. Master dissertation, University of Mentouri.

[28] Saadou, M. (1990). La végétation des milieux drainés nigériens à l'Est du fleuve Niger. PhD dissertation, Faculty of Sciences, University of Niamey.

[29] Salt, D. E., Blaylock, M., Kumar, P. B. A., Dushenkov, V., Ensley, B.D., Chet, I., Raskin, I. (1995). Phytoremediation: A Novel Strategy for the Removal of Toxic Metals from the Environment Using Plants. Bio/Technol. 1:468-474.

[30] Seidl, M., Mouchel, J. M. (2003). Valorisation des eaux usées par lagunage dans les pays en voie de développement. Centre d'Enseignement et de Recherche Eau Ville Environnement, 7-10.

[31] Shannon, C. E., Weaver, W. (1949). The mathematical theory of communication. Univ Illinois Press Urbana, $117 \mathrm{p}$.

[32] Tankari, D. A. (2011). Evaluation des risques de transferts des éléments traces métalliques des sols aux légumes et fourrages dans la zone Urbaine de GountiYéna. Convention N007 - CPU-AIRD-INPL - Faculty of Agronomy, University of Niamey.

[33] Tankari, D. A., Géuro, Y., Dan Lamso, N., Tidjani, A. D., Ambouta, K. J. M., Feidt, C., Sterckeman, T., Echevarria, G. (2013). Evaluation de la contamination des sols par les éléments traces métalliques dans les zones urbaines et périurbaines de la ville de Niamey (Niger). Revues Université Ouargla. 2(5) :110-119.

[34] Tchaou, M. C. (2011). Contribution à l'amélioration du système de gestion des déchets solides urbains dans la commune de Lomé: Cas du quartier GBADAGO. Master dissertation, University of Lomé, 51p.

[35] Vaillant, N., Monnet, F., Hitmi, A., Sallanon, H., Coudret, A. (2005). Comparative study of responses in four Datura species to a zinc stress. Chemosphere. 59:1005-1013. 